\title{
A conceptual framework for ecological economics based on systemic principles of life
}

\author{
Fritjof Capra \\ Center for Ecoliteracy, Berkeley, California, USA, and \\ Ove Daniel Jakobsen \\ Nord University, Bodø, Norway
}

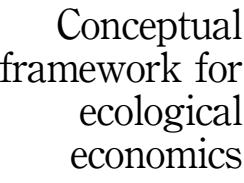

831

Received 25 May 2016 Revised 2 January 2017 Accepted 28 February 2017

\begin{abstract}
Purpose - The purpose of this paper is to refer to ecological economics using two meanings of the term "ecological". In the strict scientific sense, ecological economics refers to an economic system that is consistent with and honors the basic principles of ecology, which, ultimately, are identical with what the authors call the systemic principles of life. In a broader sense ecological economics refers to economic theory and practice that see the economy as operating within, rather than dominating, the spheres of nature, society, and culture.

Design/methodology/approach - The authors distill four fundamental principles for ecological economics based on systems theory of life and philosophy of organism. The four principles are; nested systems, self-generating networks, open systems, and cognitive interactions. The authors discuss how these principles can be applied to design an ecological economic system that is life-enhancing on individual, social and ecological levels.

Findings - The authors argue that ecological economics should give priority to activities that maximize well-being of human and non-human beings, as well as entire ecosystems, and that its central purpose should be to serve the life processes in social and ecological systems.

Originality/value - In this paper, the authors connect ecological economics to systems theory and come up with principles relevant for developing economic theory and practice within, rather than dominating, the spheres of nature, society, and culture.
\end{abstract}

Keywords Ecological economics, Systems theory, Nested networks, Philosophy of organism

Paper type Conceptual paper

\section{Introduction}

Today's global economy has put ecosystems and societies into critical distress, and we have to go to the very root of the problems to find new solutions. To solve problems it is not sufficient to make changes within established economics (environmental economics); fundamental changes in economic theory and practice (ecological economics) are required. There is a need for a new transdisciplinary economics which unites opposites and creates basis for peace in ourselves, between people and between people and nature. Today's economy generates conflict in all areas. In this paper, we suggest a new conceptual framework for economic theory and practice based on systemic principles of life.

It is obvious that the dominating economy involves a great deal of violence against people and nature. The gap between rich and poor is increasing, natural resources are ruthlessly exploited. Loss of biodiversity and climate change are examples indicating that nature's rhythm and balance are dramatically disturbed. In addition to that, the economy itself is in a bad condition. In the words of sociologist Ruth Levitas (2013), "the economic shockwaves of 2008 and the ensuing global recessions laid bare the instability of global

(C) Fritjof Capra and Ove Daniel Jakobsen. Published by Emerald Publishing Limited. This article is published under the Creative Commons Attribution (CC BY 4.0) licence. Anyone may reproduce, distribute, translate and create derivative works of this article (for both commercial and non-commercial purposes), subject to full attribution to the original publication and authors. The full terms of this licence may be seen at http://creativecommons.org/licences/by/4.0/legalcode

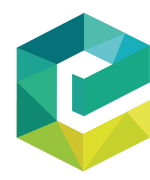

International Journal of Social Economics Vol. 44 No. 6,2017 pp. $831-844$ $0306-8293$ DOI 10.1108/IJSE-05-2016-0136 
IJSE

44,6

capitalism and its inability to provide sustainable livelihoods for the world's population" (p. xi). What we need is a reconstruction of economy (and society) based on a combination of imagination and a far deeper understanding of reality. Anthony Giddens, thinking along these lines, argued 26 years ago that we had to look for an alternative worldview to the existing one, which pursues a course of self-destruction. As an example he claimed that "the pursuit of capitalist accumulation could not be carried out indefinitely since it is not selfsustaining in terms of resources" (Giddens, 1990, p. 165).

From Whitehead's perspective, a successful worldview should be capable of interpreting the complex texture of both nature and society. In addition, the humanizing of technology is likely to involve the introduction of moral issues into the now largely "instrumental" relation between human beings and the created environment. In the philosophy of organism, Whitehead describes the context for an economy based on some broad principles. He claims that we all know intuitively what a good society means. "It suggests a certain ideal for life on Earth, and this ideal concerns both the individual human being and also societies of men" (Whitehead, 1967, p. 273).

A civilized society should exhibit the five qualities of "truth, beauty, adventure, art, and peace" (Whitehead, 1967, p. 274). Whitehead scholar Johnson (1962) adds that "all five qualities should be exhibited in all phases of experience" (p. 1). Adventures and art, including spontaneity and freshness, are the most important ingredients in civilization. They involve freshness, spontaneity, and the contrast of what is (actuality) and what might be (potentiality). A work of art is an impressive demonstration of creative powers. "It not only expresses, but also arouses, new ideas and 'freshness' of emotion” (Johnson, 1962, p. 8).

Johnson (1962) points at a very important aspect of the philosophy of organism when he states that "if something new and better is to be enjoyed, something old and less valuable must be discarded" (p. 3). Whitehead (1967) expresses hope that "our present epoch is to be viewed as a period of change to a new direction of civilization, involving in its dislocations a minimum of human misery" (p. 278). To succeed in this change process, he argues that thought has to run ahead of realization. "The vigor of the race has then pushed forward into the adventure of imagination, so as to anticipate the physical adventures of exploration" (Whitehead, 1967, p. 279).

Civilization also includes peace, not as the absence of war, but as a notion of harmony that binds the other four qualities together. It is a positive feeling, hard to define and even difficult to speak about - "a broadening of feeling due to the emergence of some deep metaphysical insight, unverbalized and yet momentous in its coordination of values" (Whitehead, 1967, p. 285). The first effect of peace, according to Whitehead, is a surpassing of personality and the removal of the stress of acquisitive feelings arising from the soul's preoccupation with itself. Thus, peace is self-control at its widest, "at the width where the 'self' has been lost, and interest has been transferred to coordinations wider than personality” (Whitehead, 1967, p. 285).

When we look at the state of the world today, what is most evident is the fact that the major problems of our time cannot be understood in isolation. They are systemic problems which mean that they are interconnected and interdependent. It is not satisfactory to implement measures at the level of symptoms. To solve systemic problems, systemic solutions are required. As Francis (2015, p. 69) puts it in his remarkable encyclical "Laudato Sì:

Our common home is falling into serious disrepair [...] [This is] evident in large-scale natural disasters as well as social and even financial crises, for the world's problems cannot be analyzed or explained in isolation [...]. It cannot be emphasized enough how everything is interconnected" (paragraphs 61, 138).

Unfortunately, this understanding has not yet become clear to most political and business leaders. They are still unable to "connect the dots," to use a popular phrase. Instead of taking into account the interconnectedness of reality their "solutions" tend to focus on isolated 
issues, thereby simply shifting the problem to another part of the system. For example, by stimulating economic growth, environmental problems, such as loss of biodiversity, and climate change, increase. Stricter regulations relating to environmental and social responsibility often have negative economic consequences. The challenge is to develop an economy that unites opposites without coming into conflict with nature and society.

More generally, the dominating context of understanding is often connected to shortsighted perspectives. According to Segall (2013), "our scientific way of knowing constructed on the metaphysical assumption of the bifurcation of subject and object, fact and value, meaning and matter" (p. 19), threatens the continued existence of the community of life on Earth. We can conclude that scientific materialism leaves us in the impossible position of having to deny in theory what we are unable to deny in practice.

What we need is solutions that are systemic and sustainable from a long-term perspective. Instead of building economies (and societies) on knowledge focused on how to conquer nature, the great challenge of our time is to build and nurture sustainable communities designed in accordance with living nature. The idea that research should come up with knowledge that gives human beings power over nature must be replaced by a new approach to science. The aim should be to develop knowledge that teaches us how we can adapt economy to the principles found in nature.

The mechanistic worldview, describing the universe as a machine composed of elementary building blocks, has lost its dominating position in favor of an organic worldview describing the material world as a network of inseparable patterns of relationships; and "that the planet as a whole is a living, self-regulating system" (Capra and Henderson, 2009, p. 7).

While the social Darwinists of the nineteenth Century saw only competition in nature, we are now beginning to see continual cooperation and mutual dependence among all life forms as central aspects of evolution. Evolution is no longer seen as a competitive struggle for existence, but rather as "a cooperative dance in which creativity and the constant emergence of novelty are the driving forces" (Capra and Henderson, 2009, p. 7). To illuminate this very important point Capra (1997) refers to Margulis and Sagan, who ascerts; "Life did not take over the globe by combat, but by networking" (p. 226). Based on the fundamental ideas of complexity, networks, and patterns of organization, a new holistic science is slowly emerging.

Capra and Luisi (2014) call this new science "the systems view of life" because it is grounded in "systems thinking," or systemic thinking - thinking in terms of relationships, patterns, and context. The systems view of life has important applications in almost every field of study and every human endeavor, because most phenomena we deal with in our professional and personal lives have to do with living systems. Whether we talk about economics, the environment, education, healthcare, law, or management, we are dealing with living organisms, social systems, or ecosystems. And consequently, the fundamental shift of perception from the mechanistic to the systemic view of life is relevant to all these areas.

We have the opportunity to create a future consistent with "our true nature and possibility as living beings born of a Living Earth" (Korten, 2015, p. 1). Scarcity can be overcome, conflict reconciled, and moral dilemmas and psychological frustrations resolved (Davis, 2012, p. 129). The question is how to develop an economy that strengthen nature's inherent ability to sustain life. In other words, the economy must adapt to ecological limits and principles.

In this paper, we distill a few fundamental principles from the systemic conception of life and Whitehead's philosophy of organism, and discuss how these principles can be applied to design an ecological economic system that is life-enhancing rather than life-destroying. The corresponding economic practices will differ depending on cultural and natural conditions, just as ecosystems are different depending on environmental conditions. However, the underlying principles are the same; they are universal systemic principles of life. We should emphasize that the recognition of these principles is not restricted to science.

\section{Conceptual framework for ecological economics}


IJSE

44,6

Similar ideas can be found, in various schools of Buddhism, and in numerous indigenous cultures. Hence, the systems view of life and the philosophy of organism are unifying visions, uniting East and West, North and South.

Our approach to ecological economics exceeds the traditional definition in that we explicitly are using two meanings of the term "ecological". In the strict scientific sense, ecology is the science of relationships between the members of an ecological community and their environment. In this sense, ecological economics refers to an economic system that is consistent with and honors the basic principles of ecology, which, ultimately, are identical with what we call the systemic principles of life. In a broader sense, ecology refers to a pattern of relationships that define the context for a certain phenomenon. In this broad sense, ecological economics refers to economic theory and practice that see the economy as operating within, rather than dominating, the spheres of nature, society, and culture.

\section{Frame of reference - systems thinking}

Inspired by dialogues amongst researchers representing social sciences, natural sciences, and the humanities, systems thinking was developed in the 1920s and 1930s (Capra, 1997). Through the exchange of ideas in their interdisciplinary networks the scientists realized that living systems, in contrast to mechanical constructions, are integrated wholes characterized by their relations, their properties being different from those of the smaller parts. Consequently, systems theory involves a shift of perspective from the parts to the whole. This vision was articulated by the now well-known phrase, "The whole is more than the sum of its parts". The essential properties of a living system arise from the dynamic connections among the parts. The interconnectedness between organisms and their natural and societal environment has several consequences.

Among Western philosophers, Alfred North Whitehead perhaps comes closest to the systems view of life. With his "philosophy of organism," also known as "process philosophy," Whitehead developed an organic context for interpreting the world we live in. According to Whitehead, reality does not consist of isolated material building blocks, but rather of primary "events" that are fundamentally interrelated and interdependent.

First, relations are more important than objects. This means that every organism is constituted by its connections to other organisms. From this ontological position, it is reasonable to claim that all entities derive their character from the social and ecological networks they are integrated parts of. The study of relationships affects not only the relationships among the system's components, but also those between the system as a whole and surrounding larger systems. Therefore systems thinking is always contextual thinking, all systems are part of larger systems (context).

Second, every organism develops as integrated parts of numerous different processes, which are interwoven with one another. Living organisms are more than a static configuration of components in a whole. While the form is maintained, there is a continual flow of energy and matter through all living systems. Natural growth is characterized by growth and decay, regeneration and development. Hence, living organisms are inseparably linked to metabolic and dynamic processes. These processes can be understood from both an individual and a systemic perspective. We can consider the formation of the system from the characterization of the individuals; "or we can characterize the individuals and conceive them as formative of the relevant process" (Whitehead, 1966, p. 98).

Thus, systems thinking includes both contextual thinking and process thinking. This transformation in perspective has important methodological consequences. Instead of measuring quantities, the focus is adjusted to mapping patterns of relationships. When we map relationships, we find certain configurations that occur repeatedly. Consequently, focusing on relationships and process instead of objects indicates a shift from quantity to quality. 
The parallel to the view of living organisms as self-generating networks, interconnecting basic metabolic processes, is obvious. Whitehead seeks to replace the traditional scientific conception of the universe as a mechanism with a novel conception of a living, selforganizing system. Nature is a theater for the interrelations of activities: "All things change, the activities and their interrelations" (Whitehead, 1977, p. 15).

The systems view of life shows us that all living systems share a set of common properties and principles of organization. These universal and fundamental principles are what we call in this paper the systemic principles of life. Throughout the living world, we find multileveled structures of systems nested within systems. Each individual system is an integrated whole and, at the same time, part of larger systems. For example, the human organism contains organs made of tissues which, in turn, are made of cells. On the other hand, the organism as a whole is embedded in larger social systems which, in turn, are embedded in ecosystems. We identify this principle of nested systems as the first of our systemic principles of life.

The basic pattern of organization of a living system is the network. Ecosystems are understood in terms of food webs, i.e. networks of organisms; organisms are networks of cells, and cells are networks of molecules. More precisely, a living system is a self-generating network within a boundary of its own making. Each component of the network helps to transform and replace other components, and thus the entire network continually creates, or recreates, itself. In this way, living systems undergo continual structural changes while preserving their web-like patterns of organization. The principle of self-generating networks is our second systemic principle of life.

A living system is materially and energetically open and always operates far from equilibrium. There is a continual flow of energy and matter through the system. All living systems need energy and food to sustain themselves, and all living systems produce wastes. But in nature, organisms form communities, the ecosystems, in which the waste of one species is food for the next, so that matter cycles continually through the ecosystem.

The dynamics of such an open system are nonlinear and involve multiple interconnected feedback loops, which allow the system to regulate and balance itself. On the other hand, there is always a potential for the spontaneous emergence of new order at critical points of instability. Actuality and potentiality are organically integrated so as to allow for a genuinely creative cosmos where, even if the past is settled, the future remains widely open. The principle of open systems is our third systemic principle of life.

And finally, all living systems are cognitive systems. They interact cognitively with their environment in ways that are determined by their own internal organization. The principle of cognitive interactions is our fourth systemic principle of life. This, then, are our four fundamental principles: nested systems, self-generating networks, open systems, and cognitive interactions. We should point out that they are all interconnected, so that the choice of what to call a fundamental principle is somewhat arbitrary. For example, the principles open systems and self-generating networks are combined in the definition of metabolism, which is a central characteristic of life. Metabolism is the ceaseless flow of energy and matter through a network of chemical reactions, which enables a living organism to continually generate, repair, and perpetuate itself.

To give another example, when the nonlinearity of living networks is manifest in ecosystems as food webs, it involves cooperation, partnerships, and symbioses - all of which might also be called principles of life. At the very heart of the change of paradigms from the mechanistic to the systemic view of life we find a fundamental change of metaphors: from seeing the world as a machine to understanding it as an organic living network.

\section{Principles of ecological economics}

In the following paragraphs we shall exemplify how our four principles can be guiding principles for a transition to an ecological economics. In a society where the systemic view of 
IJSE

44,6

836

life is accepted, the context of economics becomes one where every economic activity should contribute to the development of viable societies within resilient nature. In other words, the economy should give priority to activities that are in harmony with the overarching goal of maximizing the well-being of human beings, non-humans, and whole ecosystems. The only valid purpose of the economy is to serve the life processes in all kinds of social and ecological systems.

In her book Owning Our Future, business journalist Kelly (2012) illustrates this fundamental change with dozens of inspiring examples of organizations that are not publicly traded corporations but embody "private ownership for the common good." They include worker-owned businesses, wind farms operated by "wind guilds," marine fisheries with catch shares, cooperatives and nonprofit organizations forming a "solidarity economy," customer owned banks, and so on. What all these ownership designs have in common is that they create and maintain conditions for the flourishing of human and ecological communities. Kelly calls this new kind of ownership "generative ownership," because it generates well-being and real, living wealth. She contrasts it with the "extractive ownership" of the conventional corporate ownership model, whose central feature is maximum financial extraction, and she claims that the family of generative ownership designs is forming together a nascent generative economy.

In principle, it is possible to implement the change to ecological economics both at the individual and the systemic level. On the one hand, economic systems depend on human beings. Hence, to change the system we, as individuals, must change first. On the other hand, if the systems are bad, people will behave poorly. Hence, we have to change the systems first. In this paper we focus on systemic change, even if we agree that the two levels are mutually dependent, structural change requiring individual change and vice versa.

\section{Principle 1: economy as a nested system}

For economics, the systems view of life is revolutionary. It implies that nature is superior to the economy, not vice versa. In ecological economics, the economy becomes the servant of nature, not the master of nature. The economic system must be integrated into the organic network of reality - the web of life. All actors are integrated in cooperative networks, searching for solutions leading to the enjoyment of life within resilient ecosystems and viable social systems.

The economy is a living system nested in other living systems - society, culture, politics, nature, and ultimately Gaia, the living Earth (see Figure 1). A healthy evolutionary process depends on the harmonious balance between the different systems; no-one dominates the others.

This is in stark contrast to today's global economy, in which the economic sector has a dominant position, leading to the commercialization of politics, culture (including science), and nature. In ecological economics, the economy, interpreted as an integral part of society and nature, is filled with meaning. Every economic activity should be a servant of life.

Figure 1 .

Economy as a nested system

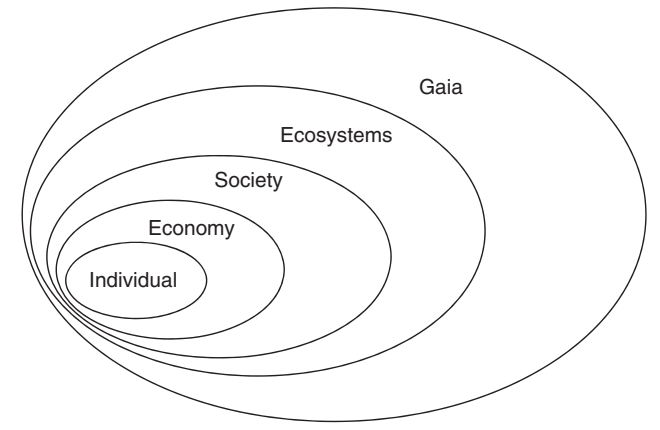


The systems view of life makes it evident that the well-being of the ecology of our planet is tied to the quality of human life.

At the level of micro-economics, the view of the economy as a nested system means that it is inappropriate to talk about a single business as being sustainable, because all businesses are embedded in social and ecological networks. Change and development, including the movement toward sustainability, depend on building and rebuilding relations between all available entities, i.e. human and natural resources.

This has been clearly recognized by the Transition Town movement, which originated in the UK in 2006 and has since spread all over the world. A Transition Town is the home of a collection of grassroots initiatives that seek to build community resilience in the face of the challenges of peak oil, climate change, and economic crises. They do so by engaging their communities in home-grown, citizen-led education and actions, based on local self-reliance, networking, collaboration, and regenerative use of their local assets (see Hopkins, 2008). As the name implies, Transition Towns are not yet sustainable but are in transition to becoming sustainable communities.

\section{Principle 2: economy as networks}

According to the systems view of life, the basic pattern of organization of all living systems is the network; and since a network is a particular pattern of connections and relationships, thinking in terms of patterns and relationships is the very essence of systems thinking. As we have emphasized, the study of relationships concerns not only the relationships among the system's components, but also the relationships between the system as a whole and its surrounding systems. The essential properties of a living system arise both from the interactions and relationships among its parts and from the relationships of the whole system to other things.

This view, that all things are integrated in dynamic networks, and that nothing can exist as an isolated atom, is in complete harmony with the philosophy of organism, which sees all organisms as interdependent both spatially and temporally. This interconnectedness between organisms and their natural and societal environment means that every organism is constituted, at least in part, by its connections to other organisms. From this ontological position, it is reasonable to claim that living entities derive much of their character from the social and ecological networks they are integrated parts of.

Such a systemic and "organismic" view of reality has several important consequences for economics. It implies that neither economy nor society are collections of objects, but are based on relationships between subjects. They function as integrated wholes and cannot survive atomized any more than any organism can survive in fragments. This means that economists and other social scientists, following the example of ecologists, need to study all processes as part of the web of life. If economics is studied separately from social and ecological contexts, and knowledge is expressed through narrowly defined mathematical models, it becomes abstract and remote from life. To understand the dynamic interconnectedness in the real world, holistic research models based on transdisciplinarity are of vital importance.

The fact that the basic pattern of organization of all living systems is the network means that an economy will be truly alive - flexible and capable of creative adaptations to changing circumstances - only if it is organized as a network, composed of smaller living networks, and integrated into larger social and ecological networks.

Hence, our environmental and social challenges should be addressed through building integrated local and regional networks where creative thinking is combined with practical experimentation. Dialogues in cooperative networks make it possible to be open for pluralistic values that exceed the economy's traditional one-dimensional monetary scale. In economics, as in the management of business organizations, everything depends on an open-minded consideration of life as a whole. We must gain a clear vision of the wholeness of life. 
IJSE

44,6

838

An economy based on local networks linked together globally provides the best basis for developing co-responsible human beings. In such an economy, local and national interests will not seem divisive in our shared responsibility as global citizens, while we can also avoid global uniformity. Internationalizing is based upon a cooperative network of small societies while globalization represents membership in an abstract global community. Globalization is not about patterns for diverse interactions; it is about the constitution of a single global economy. Diversity is a guarantee for keeping relations dynamic and avoiding that they harden in a fixed pattern, which could in the long run lead to conflict and disunity.

According to the systems view of life, living organisms interact with their environment through "structural coupling," i.e. through recurrent interactions, each of which triggers structural changes in the system (see Capra and Luisi, 2014, p. 135). Over time, different environments will trigger different structural changes, and as a consequence no organism is exactly the same as any other organism of the same species: individuality is a basic property of life.

For a living economy this means that economic processes directly or indirectly affect and are affected by individuals, businesses, communities, and the environment, depending on local and regional circumstances. Hence, economic practice should always be adapted to changing regional conditions. If economic theory and practice ignore this context, this may cause serious negative unintended consequences, as is evident in today's environmental, social and financial crisis.

\section{Diverse money systems}

Another important property of living systems is their resilience. They are able to absorb disturbances, reorganize, and retain their effective functioning. This resilience is closely connected with the system's diversity. A diverse ecosystem, for example, will be resilient, because it contains many species with overlapping ecological functions that can partially replace one another. When a particular species is destroyed by a severe disturbance so that some links in the network are broken, a diverse ecological community will be able to survive and reorganize itself, because other links in the network can at least partially fulfill the function of the destroyed species.

Similarly, the resilience of crops to extreme climate events is closely linked to agricultural biodiversity. Surveys conducted after major climate disasters - e.g., Hurricane Mitch in Central America and Hurricane Ike in Cuba - have shown that farms using agro-ecological practices, characterized by high biodiversity, suffered less damage than neighboring conventionally farmed monocultures (see Altieri et al., 2012). In living systems, resilience and efficiency are interdependent: high efficiency means low resilience and vice versa. Sustainability requires an optimal balance of these two variables. Lietaer (2014) argues that our official economic system is not resilient because it is a monoculture, based on a single official currency. To make it resilient, we need monetary diversity, i.e. alternative currencies that are complementary to the official currency. In fact, a variety of such local, alternative currencies have emerged over the recent decades. They are less efficient than the official currency, but, according to Lietaer (2014), this is precisely why they make the financial system more resilient. What we need, in the words of Lietaer, is "a monetary ecosystem".

\section{The function of banks}

Banks play an essential role in economic life where the material basis for human societies is created. In our interpretation of ecological economics one of the most important functions of the banks is to connect money systems to the real economy, or to build a bridge of common interest between the two spheres of the economy. The banks could inspire cooperation between actors by focusing on common purposes in a long-term perspective. The motivation is not narrow self-interest, but the coming together of common interest and personal responsibility. Integrated networks of small-scale local businesses are 
characterized by diversity in production, processing, distribution, and retro distribution (reprocessing).

Local currency is of great importance, because it is an effective incentive for customers to buy products from the region. In other words, local currency is linking all economic actors in the region together in flexible and dynamic networks. According to this line of reasoning, the banks should manage a variety of different currencies oriented toward initiating resilient local communities. A prerequisite is that these social and ecologically responsible banks are cooperatively owned and locally rooted.

To inspire to sustainable development instead of unsustainable growth, local currencies with negative interest give strong incentives to use local resources. Deep respect for the commons is essential. If the banks manage a variety of different currencies and give credit in response to local needs and opportunities through processes that are transparent and democratically accountable, money could have significant impact on the development of resilient societies all over the world.

Instead of focusing on finance speculation aiming to multiply profits, the overarching objective should be to stimulate qualitative growth - growth in knowledge and skills. Regional currency helps to strengthen the region's economy; it also helps developing people's identity and sense of belonging to their community. Regional currency establishes a protective membrane between the region and the world.

\section{Nested networks}

Local networks linked together nationally and globally provide the best basis for developing co-responsible human beings, as we have mentioned. The main thing to emphasize here is that individual citizens in the global network should maintain their individuality and dignity. In addition to local, bottom-up initiatives, the development of global democratic institutions (top-down) with the authority to regulate the world economy are of great importance. A combination of bottom-up (personal responsibility) and top-down principles (international treaties) is necessary to secure that the total consumption of natural resources is kept within critical levels. All economic activity depends on access to natural resources.

In accordance with the systems view of life and the philosophy of organism, creativity is seen as the driving force in development. Creativity depends on the individual freedom to actualize the potential existing in local societies. A living economy presupposes the existence of arenas for free exchange of ideas, knowledge, and information. Open information systems lead to democratic decision making. Dialogue stimulates everyone to contribute according to their ability, and recognizes the right of each to meet their reasonable needs with due consideration for the needs of others.

In a society based on organic interdependence, economies are characterized by cooperation instead of ruthless competition. Whereas mechanical systems and bureaucracy stifle creativity, decentralized structures, based on local ownership and local decision making, stimulate creativity. Globalized corporations tend to do business with an abstract competitive market, while small enterprises, nested in networks, are cooperating with living actors. In such a real-life context technological development expands from improving ecoefficiency to emphasizing ecological and social resilience.

If we accept that social systems and ecosystems are integrated nested networks, we can develop an economic system where the focus is on establishing and building dynamic interrelations between the actors. One of the best ways to build such an economic system would be to start with a network of interconnected decentralized ecovillages, communities that exist today around the world, striving to live sustainably, restore the land, and often experimenting with new forms of communal governance and decision making (see Joubert and Leila, 2015). These ecovillages would form the basic units of the economy, and the scale of industrialization would be planned accordingly. 
IJSE

44,6

840

The systemic principles of "self-generating networks" and "nested systems," taken together, lead to the vision of a living economy in which all kinds of economic activities are interrelated and connected to self-organizing and mutually supportive entities. Local initiatives and local currency favor the use of local energy, nutrients, water, and material resources. Local currencies are used to stimulate the integrity of the community, support fair and balanced trade surplus with neighbors, secure the community's resources against theft by intruding predators (multinational companies), and to maintain boundaries around local societies.

\section{Principle 3: economy, as an open system}

Our systemic principles of life concern two main aspects of living systems: networks and flows. These two perspectives are unified in the concept of metabolism, the central characteristic of life. Metabolism, as we have mentioned, is defined as the ceaseless flow of energy and matter through a network of chemical reactions, which enables a living organism to continually generate, repair, and perpetuate itself. In our discussion of the principles of ecological economics we have until now addressed various implications of the network perspective, and we must now turn to the perspective of flows.

As we have mentioned, all living systems need to be open to continual flows of energy and matter, and all living systems produce wastes. In nature, however, organisms form communities, the ecosystems, in which the waste of one species is food for the next so that matter cycles continually through the ecosystem, while energy is dissipated at each stage. The only waste generated by the ecosystem as a whole is the heat energy of respiration, which is radiated into the atmosphere and is replenished continually from the sun through photosynthesis.

For a living economy this means that all economic processes need to be circular in three dimensions. Referring to the Gaia theory by James Lovelock and Lynn Margulis, we argue that ecological economics recognizes that economy, nature, and culture are integrated parts within a "living" organism (Lovelock, 1988). The art of progress is to preserve order amid change (Whitehead, 1967). First of all, economic value chains must change from linearity to circularity. Retro distribution, connecting consumption and production, consists of several sub-functions, including collecting, sorting, and reprocessing of various materials (see Figure 2). Circular value chains make it possible to reduce both the consumption of virgin natural resources and the amount of waste that goes back to nature. To establish efficient material cycles in practice, collaboration between governments, manufactures, distributors, and consumers are required.

Second, circularity is the basis of the connection between economy and nature. Sustainability depends on our ability to discover the connections between input and output

Figure 2.

Circulation economics

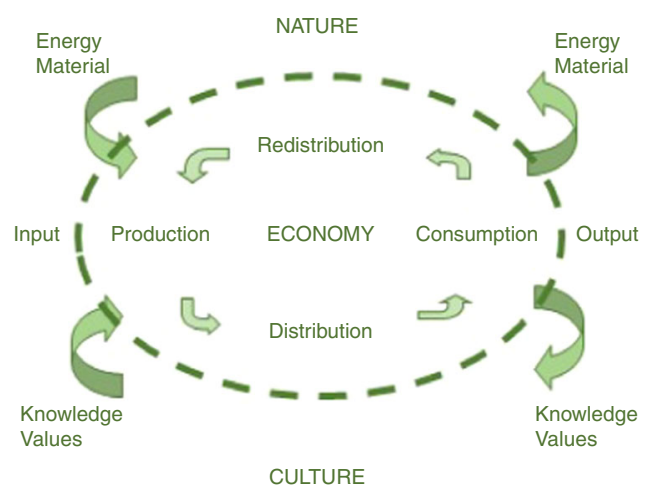

Source: Ingebrigtsen and Jakobsen (2007) 
of natural resources in the economic value chains. To develop a life-enhancing economy it is necessary to cooperate with nature on both sides. In this perspective, $\mathrm{CO}_{2}$ is not a cause; it is a symptom of a carbon-based economy. In other words, to handle climate change we have to be aware of the patterns of interconnectedness between the input and the output side of the economy.

Finally, economy and culture also have a circular connection. Knowledge and values are essential to develop a life-enhancing economy. "On the one hand, knowledge exerts influence on the innovative processes in the economy and on the other hand changes in the economic sector influence cultural development" (Ingebrigtsen and Jakobsen, 2007, p. 289). To understand how the economy works, contextual thinking, including nature and culture, is a prerquisite.

To build such a circular economy, our technologies and industrial systems need to be fundamentally redesigned, mimicking the natural ecological cycles. This is one of the main tasks of ecodesign. Indeed, ecodesigners today are promoting the idea of a "service-andflow" economy, involving two kinds of metabolism - a biological metabolism and a "technical metabolism" (see McDonough and Braungart, 1998).

Matter that cycles in the biological metabolism is biodegradable and becomes food for other living organisms. Materials that are not biodegradable are regarded as "technical nutrients," which continually circulate within industrial cycles that constitute the technical metabolism. In order for these two metabolisms to remain healthy, great care must be taken to keep them distinct and separate, so that they do not contaminate each another. Things that are part of the biological metabolism - agricultural products, clothing, cosmetics, etc. - should not contain persistent toxic substances. Things that go into the technical metabolism - machines, physical structures, etc. - should be kept well apart from the biological metabolism.

\section{From quantitative growth to qualitative development}

In addition to growth and development, the metabolic flows of energy and matter in living organisms are necessary for the continual regeneration and recycling of organic components. There is a significant difference between growth in organic and mechanical perspectives. In both perspectives growth is of central importance. Within a mechanical worldview linear (or exponential) and unlimited growth is common. Natural growth, within an organic system, is characterized by dynamic change where certain parts of organisms, or ecosystems, grow, others decline, releasing and recycling their components which become resources for new growth.

This kind of balanced, multi-faceted growth, well-known to biologists and ecologists, is in stark contrast to the concept of perpetual linear (or exponential) growth held by most of our economists and politicians. Unlimited economic growth on a finite planet is logically impossible. The objective of boundless quantitative growth is thus a dangerous misconception, which can be seen as the ultimate dilemma underlying most of our global problems.

In our economic system, perpetual growth is pursued by intensive marketing aiming to increase the amounts of all kinds of products through excessive consumption and a throwaway economy. The serious consequences of such an energy and resource intensive economy is increasing amounts of waste and pollution, leading towards disturbance of ecosystems and depleting the Earth's natural resources. Moreover, these environmental problems are exacerbated by global climate change, caused by our energy-intensive and fossil-fuel-based technologies. The irrational belief in perpetual economic growth amounts to a clash between linear thinking and the nonlinear patterns in our biosphere - the ecological networks and cycles that constitute the web of life. This highly nonlinear global network contains countless feedback loops through which the planet balances and regulates itself. Our current economic system, by contrast, is fueled by materialism and greed that do not seem to recognize any limits. 
IJSE

44,6

842

Ecological economics, by contrast, advocates the urgently needed shift from quantitative growth to qualitative development. Such qualitative development involves growth that enhances the quality of life through generation and regeneration. In living organisms, ecosystems and societies, qualitative development includes an increase of complexity, sophistication, and maturity. Ecological economics, anchored in the systems view of life, is intrinsically dynamic and assumes continuous development without increased consumption of natural resources. Instead of using one-dimensional instrumental thinking aiming at increased growth and profits, our energy and efforts should aim at greater complexity, beauty, and harmony. We have organized our economic thinking around a very bad idea: that we should work for money (Scharmer, 2009).

The focus on qualitative development is fully consistent with the "philosophy of organism" and the new systemic conception of life. The new science includes qualities arising from processes and patterns of integrated relations between the entities (actors) in the living networks. If we, in accordance with mainstream economists, describe networks in purely quantitative terms, such as the undifferentiated index of the gross domestic product (GDP), we miss the nature of complexity characterizing organisms, economy, societies, and ecosystems. "Quantities can be measured; qualities need to be mapped" (Capra and Henderson, 2009, p. 7).

Therefore, what we need to assess the health of an economy are qualitative indicators of poverty, health, equity, education, social inclusion and the environment - none of which can be reduced to money-coefficients or aggregated into a simple number. Indeed, several economic indicators of this kind have recently been proposed (see "Beyond GDP," www.beyond-gdp.eu).

\section{Principle 4: economy as cognitive interactions - a sense of ethics}

According to the systems view of life, all living systems interact cognitively with their environment in ways that are determined by their own internal organization. This is our fourth systemic principle of life. In the human realm, these cognitive interactions involve consciousness and culture, and in particular a sense of ethics. Our global economy, by contrast, is a network of financial flows that has been designed mechanically without any ethical framework. In fact, social inequality and social exclusion are inherent features of economic globalization, widening the gap between the rich and the poor and increasing world poverty. It is therefore most urgent to reintroduce an ethical framework within the context of communicative cooperation between co-responsible economic actors on all levels.

Ethics is usually associated with philosophy or religion, but it can also be considered from a scientific - or, perhaps, from a scientific and spiritual - perspective. When we study the long history of the evolution of life on Earth, we come to realize that nature sustains life by creating and nurturing communities. As soon as the first cells appeared on Earth, they formed tightly interlinked communities, known as bacterial colonies; and for billions of years, nature has maintained such communities at all levels of life. Natural selection favors those communities in which individuals act for the benefit of the community as a whole. In the human realm, we call this ethical behavior. So, ethics always has to do with community; it is behavior for the common good.

Today, we belong to many different communities, but all of us have two communities in common. We are all members of humanity, and we belong to oikos, the Earth Household, which is the Greek root "ecology." In other words, we all belong to the ecological community of the global biosphere. As members of humanity, we need to respect human dignity and human rights; as members of the Earth Household, we need to respect nature's inherent ability to sustain life.

Thus, ethical behavior today should be based on the two fundamental values of human dignity and ecological sustainability. If we do not succeed in incorporating these ethical values into our personal lives, businesses, politics, and our economies, natural selection will see to it that humanity does not survive. To establish principles for global ethical behavior behavior for the common good of humanity and the Earth Household - is quite a challenge, but fortunately we have a magnificent document that covers the broad range of ecological 
sustainability, human dignity and human rights. It is the Earth Charter, a global declaration of 16 values and principles for building a just, sustainable, and peaceful world (see www. earthcharterinaction.org/content/pages/Read-the-Charter.html).

The Earth Charter makes it evident that the principles of sustainability, justice, and peace are all interconnected. Truly sustainable development demands more than reducing our negative impact on nature. Equally important measures are contributions to fairness and to reducing the gap between rich and poor. Justice is a necessary condition for peaceful development.

From a systemic perspective, it is easy to see why a more equal economy functions better. The market is a network of integrated actors where customers, suppliers, competitors, communities, and other stakeholder groups are depending on each other. In such a situation, trust and responsibility are essential values. Cooperation, based on dynamic dialogue, allows more integrated solutions than the mechanisms of an atomistic and competitive economy. Equality and mutuality among the involved actors are necessary conditions for constructive cooperation. "When competition is replaced by cooperation as the main principle for interaction in the market, the development of solutions based upon the common good will gradually take place" (Ims and Jakobsen, 2006). As sociologist and philosopher Jürgen Habermas (1982) explains, "cooperation presupposes that the partners disclose relevant and valid information without strategic action” (pp. 263-271).

In ecological economics, cooperation is the fundamental principle for the coordination of activities, while competition has a subordinate function. "The competitive autonomous economic man has to be replaced by a cooperative social ecological man" (Ingebrigtsen and Jakobsen, 2009). We claim that the systems view of life provides a better and more accurate description of the interplay between the actors in the market than an atomized description referring to autonomous actors in a competitive markets do. Market behavior based exclusively on competition will often lead to disintegration and egocentric behavior. We must replace greed, competition, and growth with solidarity, cooperation, and compassion.

\section{Concluding remarks}

To build an alternative economic system along the lines discussed in this paper the basic systemic principles of life must be understood at all levels. In recent years, this understanding has become known as ecological literacy, or "ecoliteracy."

In the coming decades the survival of humanity will depend on our ability to understand the basic principles of ecology and to develop and practice an economic system accordingly. This means that ecoliteracy must become; "a critical skill for politicians, business leaders, and professionals in all spheres, and should be the most important part of education at all levels, from primary and secondary schools to colleges, universities, and the continuing education and training of professionals" (Capra, 2012).

We live in a world of uncertainty, rich in potential for disaster and at the same time for positive possibilities. We have to realize that we never will find solutions to our current challenges using the old maps, to do more than reducing negative symptoms we have to change our worldview. As indicated by Johnson (1962) if something new and better is to be enjoyed, something old and less valuable must be discarded" (p. 1). We argue that the only valid purpose of the economy is to serve the life processes in all kinds of social and ecological systems. In accordance with Whitehead we conclude that every activity and every process within the economy should be a servant of life based on "truth, beauty, adventure, art, and peace".

\section{References}

Altieri, M., Nicholls, C. and Funes, F., other members of SOCLA (Sociedad Cientifica Latinoamericana de Agroecologia (2012), "The scaling-up of agroecology: spreading the hope for food sovereignty and resiliency", May, available at: www.agroeco.org/socla

Capra, F. (1997), The Web of Life - A New Synthesis of Mind and Matter, Flamingo, London. 
IJSE

44,6

Capra, F. (2012), Ecological Literacy, Resurgence \& Ecologist Magazine, No. 272, May/June.

Capra, F. and Henderson, H. (2009), "Outside insights - qualitative growth", Sustainable Business Initiative, London.

Capra, F. and Luisi, P.L. (2014), The Systems View of Life - A Unifying Vision, Cambridge University Press, Cambridge.

Davis, L. (2012), "History, politics, and utopia: toward a synthesis of social theory and practise", in Vieira, P. and Marder, M. (Eds), Existential Utopia - New Perspectives on Utopian Thought, Continuum, London, pp. 35-51.

Francis, P. (2015), "Laudato Si - on care for our common home", Catholic Truth Society, Vaticana, May 24, available at: w2.vatican.va/content/francesco/en/encyclicals/documents/papafrancesco_20150524_ enciclica-laudato-si.html

Giddens, A. (1990), The Consequences of Modernity, Stanford University Press, Stanford, CA.

Habermas, J. (1982), "A reply to my critics", in Thompson, J. and Held, D. (Eds), Habermas, Critical Debates, Macmillan Press, Cambridge, MA, pp. 219-284.

Hopkins, R. (2008), The Transition Handbook, Chelsea Green, White River Junction, VT.

Ims, K. and Jakobsen, O. (2006), "Cooperation and competition in the context of organic and mechanic worldviews? A theoretical and case based discussion", Journal of Business Ethics, Vol. 66 No.1, pp. 19-32.

Ingebrigtsen, S. and Jakobsen, O. (2007), Circulation Economics - Theory and Practice, Peter Lang, Oxford.

Ingebrigtsen, S. and Jakobsen, O. (2009), "Moral development of the economic actor", Ecological Economics, Vol. 68 No. 11, pp. 2777-2784.

Johnson, A.H. (1962), Whitehead's Philosophy of Civilization, Dover Publications, Inc., New York, NY.

Joubert, K. and Leila, D. (Eds) (2015), Ecovillage, Global Ecovillage Network, Triarchy Press, Devon.

Kelly, M. (2012), Owning Our Future, Berrett-Koehler, San Francisco, CA.

Korten, D.C. (2015), Change the Story; Change the Future - A Living Economy for a Living Earth, Berrett-Koeler Publishers, Inc., Oakland.

Levitas, R. (2013), Utopia as Method - The Imaginary Reconstruction of Society, Palgrave Macmillan, New York, NY.

Lietaer, B. (2014), "Why we need a monetary ecosystem", INRIA, available at: www.lietaer.com

Lovelock, J. (1988), The Ages of Gaia, Norton, New York, NY.

McDonough, W. and Braungart, M. (1998), "The next industrial revolution”, Atlantic Monthly, Vol. 282 No. 4, pp. 82-92.

Scharmer, O. (2009), Theory U - Leading from the Future as it Emerges, Berrett-Koehler Publ. Inc., San Francisco, CA.

Segall, M.D. (2013), Physics of the World-Soul - The Relevance of Alfred North Whitehead's Philosophy of Organism to Contemporary Scientific Cosmology, Amazon Ltd.

Whitehead, A.N. (1966), Modes of Thought, The Free Press, New York, NY.

Whitehead, A.N. (1967), Adventures of Ideas, Macmillan, New York, NY.

Whitehead, A.N. (1977), Nature and Life, Greenwood Press, New York, NY.

\section{Further reading}

Stiglitz, J. (2012), The Price of Inequality, Norton, New York, NY.

\section{Corresponding author}

Ove Daniel Jakobsen can be contacted at: ove.d.jakobsen@nord.no

For instructions on how to order reprints of this article, please visit our website:

www.emeraldgrouppublishing.com/licensing/reprints.htm

Or contact us for further details: permissions@emeraldinsight.com 